〔農村医学 23巻 1 号 $51 \sim 61$ 頁 昭. 49.2〕

\title{
農村乳児に多い渗出性体質の成因に関する臨床的研究
}

\author{
田坂 重 元*
}

\section{I 、はじめの䓃菜}

今を去る 34 年前, ドイツの小児科学者であるCzerny が渗出性体質なる名称を発表し，内容としては，未熟 な皮席或は粘膜が自然環境からうける刺戟が過敏に反 応する状態を言っている。かかる状態は，遠城寺は病 的体質ではないといっている如く，病人扱いはすべき ではない。ただ, 過敏の度合には個人差があるので, 部分的には単独な疾病に移行することはあり得る。し かし, Moro は, 一般的に乳児期は外界の刺戟が強く 反応し易いが，年令の增すごとに反応は次第に減弱す るといっている。かかる渗出性体質を病態生理学的に みると, 皮虐・粘膜の上皮細胞に萎縮或は角化など起 った所に微生物の感染があると, 抵抗力の弱い部分は 直ちに疾病状態を呈してくる事は日常の臨床で経験す るところである。以上の上皮細胞の保護能力の低下は 栄養学的な立場からみると, ビタミン A の減少或は欠 乏状態に一致するので, 或は渗出性体質の成因の一つ がビタミン A と何らかの関連性があるのではないかと いう想定のもとでこの研究を始めたものである。なお， ビタミン A は幼若時における皮虐粘膜等の結合組織の 発育に不可欠の役割をはたしている点も併せ考え，先 ず臨床統計的に調查をなし，ついで渗出性体質の諸症 状とビタミン A との関連についての成績を述べ考察を 加えたいと思う。

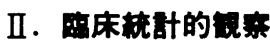

\section{a. 覾察資料}

以下述べる各地域の, 生後 1 力月頃から 1 年乃至 1 年 6 力月までの乳幼児の健康診断並びに健康相談に来 所した時のカルテが資料となった。

1) 月形町及び周辺地域(純農村) 昭和 28 年より現 在まで毎年 2 乃至 4 回実施。毎回の新来児のみ。

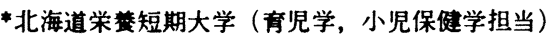

受付：昭和49年 1 月16日（特別掲韯）

本研究は, 北海道屡村医学会の研究助成（昭和 46 年 48年) に より実施したものである。
}

2 ）札县市内 4 地域（主に団地） 4 地域中，厚別地 区は昭和 24 年より毎月 1 回現在まで，白石本郷地区は 昭和 32 年より每月 1 回現在まで, 白石北郷地区は昭和 41 年より毎月 1 回現在まで, それぞれ続行中である。 白石中央地区は昭和 36 年より毎月 1 回実施してきたが, 町内会の都合によって昭和 48 年末で中止した。毎回の 新来受診児のみ。

3 ）小梅市若竹町内(勤務, 自営含む) 昭和 32 年以 来毎月 1 回実施，昭和 46 年 1 月まで続行せるも町内会 の都合で以後中止す。統計資料は昭和 45 年末までの新 来受診児のみ。

4 ) 松前町及び周辺地域(漁業 7, 農業 3 ) 昭和 40 年より毎年 1 回現在まで続行中, 受診児全部。

5 ) 渡島福島町及び周辺地域（漁業 3, 勤務 7 ) 昭 和 42 年より毎年 1 回現在続行, 受診児全部。

6 ) 別海西別町及び周辺地域(酪農業, 一部漁業) 昭和 40 年より毎年 1 回, 昭和 46 年までで, 以後, 町 の都合で中止す。受診児全部。

7 ）枝幸町及び周辺地域(農業) 昭和 45 年より毎年 1 回，現在続行中，受診児全部。

8 ）上川町及び周辺地区(農業) 昭和 46 年より毎年 1 回実施, 現在まで続行している。受診児全部。

以上の如く, 各地区の一斉健診或は健康相談を実施 してきたが，本統計資料として使用したものは，実施 後に一覧表を作り送致してもらったもののみについて まとめたものである。

\section{b. 渗出性体質判定表の作成経過}

外界の環境の変動や微生物の感染によって抵抗力の 弱い皮膚や粘膜に刺戟され過敏反応を引き起し易い体 質を，渗出性或は皮膚粘膜過敏体質と呼称しているの で，著者は昭和 35 年に第 1 表の如き判定表を作製し た。

先ず皮席に現われる反応症状と粘膜に現われる反応 症状に大きく分類し，それらを部位別に区分して，そ れぞれの部位に発来する反応症状を皮虐・粘膜のいず れも 15 項目宛とした。

次に各症状の状態判定に当って一定の点数をもって 表わそうと企図したのであるが，その内容を質で決め 
衰 1 渗出（過敏）体質判定表 (田坂考棉)

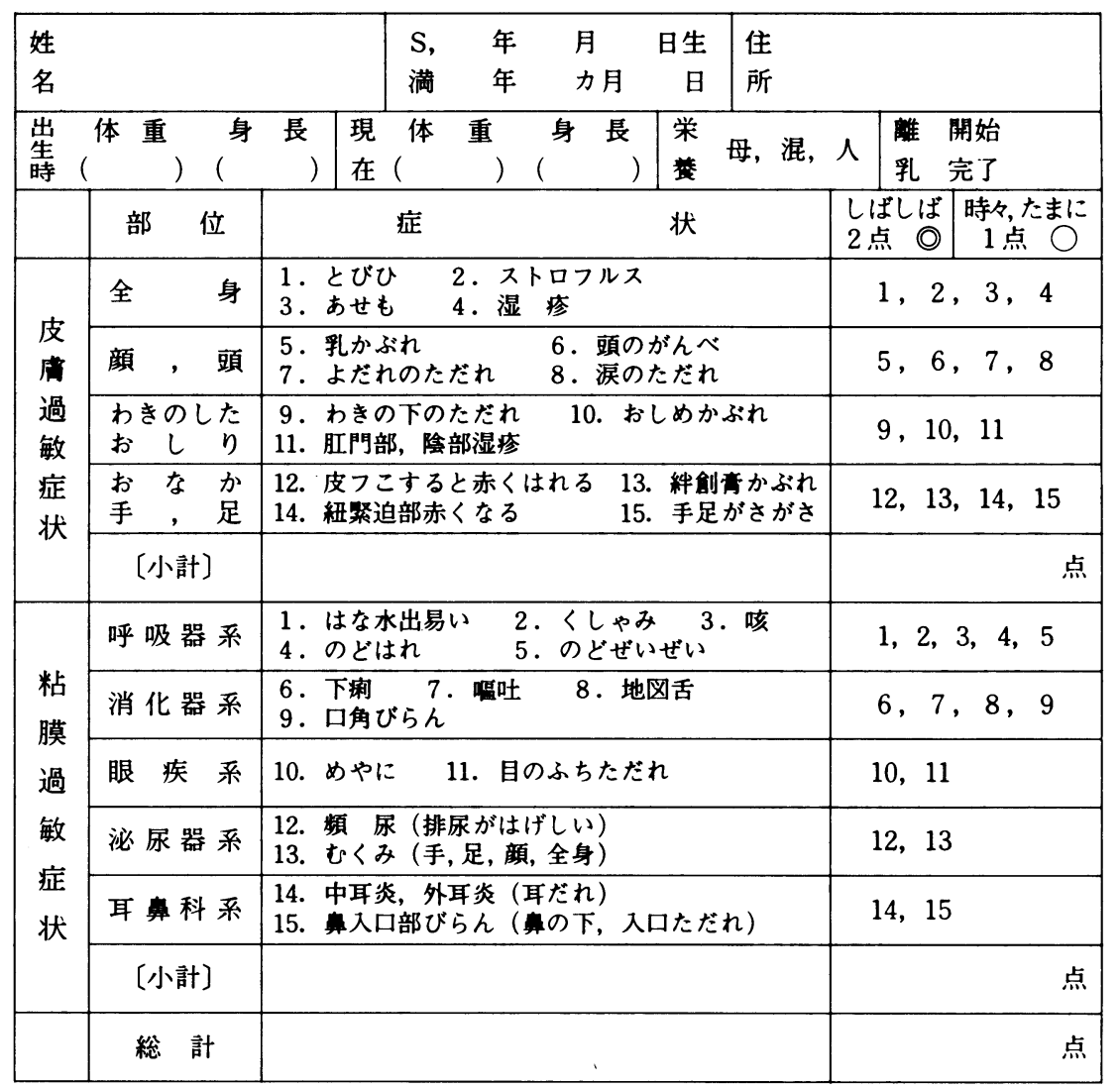

るか, 量で決めるか, という点で迷った。なかなか質 的内容で点数を決めることは困難で, 治虑の段階まで の経過が必要なため, 量的に, それもごく概念的にく り返す頻度でみたわけである。そこで, 一症状が常識 的に,「しばしば」は四季にかかわらず常にくり返し再 燃する状態を言い 2 点を与え,「たまに」或は時々再発 する状態に対して 1 点宛を与え, 皮厝・粘膜両症状の 合計点を出し, $0 \sim 2$ 点は正常体質, $3 \sim 4$ 点を渗出 性潜在体質とし， 5 点以上を渗出性体質ありとした。

\section{c. 統計的観察結果}

1) 年度別, 地区別にみた受診数に対する渗出（過 敏）体質児の割合と都鄙別平均率

第 2 表の如く，受診数に対する各地区毎に年度別に みると, 次第に郡部は減少の傾向をたどってきている。 表中, 渗体数というのは渗出性体質の症状点数 5 点以 上のものの数である。

表のうち松前, 福島, 別海, 枝幸, 上川地区は毎年 1 回の健診, しかも 7 乃至 8 月の夏期に実施している ため, 暑熱・高湿など気候不順な年度は点数の高いも
のが多くみられた。また，集団検診医が小児科医の場 合は一般医に比し, やや高率を示すことが多い。松前, 福島地区は健診（集団）後の保健婦による霏後指導が 䅡極的に実施されているため年々減少をみている。別 海は保健婦の受持つ地域があまりにも広いため, 担当 乳児数は少なくても指導の徽底を期するのが至難な結 果，その改善にはかなりの時間がかかるようである。 枝幸, 上川地区は健診指導を始めて 3 乃至 4 回故, 雨 後指導的成果が充分みえない現状である。月形地区に ついては毎年 2 乃至 3 回くり返し健診しており, 保健 婦による爾後指導も軌道にのってきているため成果は 一応上がってきた感がある。札幌及び小梅は毎月 1 回 定期的に検診を行い指導しているので, ここにかかげ てある渗体数は新来児についてのものだけ故，今後は 漸次减少していく傾向を示していくものと推察している。 都市を札幌と小㩐でまとめてみると，渗出性体質児 は平均 $26.1 \%$ に対して松前以下月形までの 6 地区を郡 部としてまとめて平均をとってみると $50.9 \%$ となり, 都市に比し農村・漁村を含めた郡部に約倍近い頻度に 
表 2 年度別及び地区別にみた受診数に対する過敏体質児の割合と都郘別平均率

\begin{tabular}{|c|c|c|c|c|c|c|c|c|c|c|c|c|c|c|c|}
\hline \multicolumn{2}{|c|}{ 地区別 } & 37 & 38 & 39 & 40 & 41 & 42 & 43 & 44 & 45 & 46 & 47 & 48 & $\begin{array}{c}\text { 受診児合計 } \\
\text { 渗体児合計 } \\
(\%)\end{array}$ & $\begin{array}{l}\text { 都䠋別 } \\
\text { 平均率 }\end{array}$ \\
\hline 松前 & $\begin{array}{c}\text { 受崄教 } \\
\text { 隐体数 } \\
\%\end{array}$ & & & & $\begin{array}{l}323 \\
235 \\
88.2\end{array}$ & $\begin{array}{l}297 \\
236 \\
90.0\end{array}$ & $\begin{array}{l}372 \\
259 \\
94.4\end{array}$ & $\begin{array}{l}299 \\
221 \\
74.3\end{array}$ & $\begin{array}{l}323 \\
200 \\
62.1\end{array}$ & $\begin{array}{l}321 \\
144 \\
44.8\end{array}$ & $\begin{array}{r}328 \\
79 \\
24.1\end{array}$ & $\begin{array}{r}325 \\
97 \\
29.9\end{array}$ & $\begin{array}{r}300 \\
94 \\
31.3\end{array}$ & $\begin{array}{l}2888 \\
1565 \\
(54.2)\end{array}$ & \\
\hline 渡島 & $\begin{array}{l}\text { 受朗教 } \\
\text { 渗体数 } \\
\%\end{array}$ & & & & & & $\begin{array}{l}218 \\
132 \\
60.5\end{array}$ & \begin{tabular}{|c|}
253 \\
198 \\
78.3
\end{tabular} & $\begin{array}{r}234 \\
79 \\
33.8\end{array}$ & $\begin{array}{r}205 \\
86 \\
41.9\end{array}$ & $\begin{array}{r}156 \\
77 \\
49.3\end{array}$ & $\begin{array}{r}182 \\
71 \\
39.0\end{array}$ & $\begin{array}{r}229 \\
82 \\
35.8\end{array}$ & $\begin{array}{r}1477 \\
725 \\
(49.1)\end{array}$ & $8179 /$ \\
\hline 別海 & $\begin{array}{c}\text { 受診教 } \\
\text { 体数 } \\
\%\end{array}$ & & & & $\begin{array}{l}268 \\
165 \\
61.6\end{array}$ & $\begin{array}{l}233 \\
143 \\
60.6\end{array}$ & $\begin{array}{l}314 \\
163 \\
57.7\end{array}$ & $\begin{array}{l}305 \\
152 \\
49.9\end{array}$ & $\begin{array}{l}319 \\
168 \\
52.7\end{array}$ & $\begin{array}{l}260 \\
123 \\
47.3\end{array}$ & $\begin{array}{r}94 \\
45 \\
47.8\end{array}$ & & & $\begin{array}{r}1793 \\
959 \\
(58.4)\end{array}$ & $=50.9$ \\
\hline 枝幸 & $\begin{array}{l}\text { 受赤教 } \\
\text { 渗体数 } \\
\%\end{array}$ & & & & & & & & & $\begin{array}{r}141 \\
81 \\
57.5\end{array}$ & $\begin{array}{r}152 \\
63 \\
41.5\end{array}$ & \begin{tabular}{|l|}
293 \\
144 \\
49.1
\end{tabular} & $\begin{array}{c}188 \\
87 \\
46.3\end{array}$ & $\begin{array}{r}774 \\
375 \\
(48.5)\end{array}$ & \\
\hline 上川 & $\begin{array}{l}\text { 受骖数 } \\
\text { 洷体数 } \\
\%\end{array}$ & & & & & & & & & & $\begin{array}{l}146 \\
109 \\
74.6\end{array}$ & $\begin{array}{r}157 \\
83 \\
52.9\end{array}$ & $\begin{array}{r}84 \\
38 \\
45.1\end{array}$ & $\begin{array}{r}387 \\
230 \\
(59.4)\end{array}$ & \\
\hline 月形 & 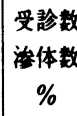 & $\begin{array}{r}63 \\
11 \\
17.5\end{array}$ & $\begin{array}{r}57 \\
13 \\
22.8\end{array}$ & $\begin{array}{r}68 \\
15 \\
22.1\end{array}$ & $\begin{array}{r}52 \\
21 \\
40.4\end{array}$ & $\begin{array}{r}64 \\
26 \\
40.6\end{array}$ & $\begin{array}{r}58 \\
26 \\
44.8\end{array}$ & $\begin{array}{r}143 \\
59 \\
41.2\end{array}$ & $\begin{array}{r}78 \\
33 \\
42.3\end{array}$ & $\begin{array}{r}70 \\
33 \\
47.2\end{array}$ & $\begin{array}{r}64 \\
27 \\
42.1\end{array}$ & $\begin{array}{r}65 \\
23 \\
35.4\end{array}$ & $\begin{array}{r}78 \\
22 \\
28.2\end{array}$ & $\begin{array}{r}860 \\
309 \\
(35.9)\end{array}$ & \\
\hline 札县 & $\begin{array}{c}\text { 受赫 } \\
\text { 港体数 } \\
\%\end{array}$ & $\begin{array}{r}42 \\
4 \\
9.5\end{array}$ & $\begin{array}{r}62 \\
8 \\
12.8\end{array}$ & $\begin{array}{r}38 \\
6 \\
15.8\end{array}$ & $\begin{array}{r}58 \\
7 \\
12.1\end{array}$ & $\begin{array}{r}59 \\
8 \\
13.6\end{array}$ & $\begin{array}{r}62 \\
11 \\
17.7\end{array}$ & $\begin{array}{r}46 \\
9 \\
19.5\end{array}$ & $\begin{array}{r}57 \\
16 \\
28.1\end{array}$ & $\begin{array}{r}66 \\
18 \\
27.3\end{array}$ & $\begin{array}{r}74 \\
22 \\
29.7\end{array}$ & $\begin{array}{r}83 \\
25 \\
30.0\end{array}$ & $\begin{array}{r}77 \\
19 \\
24.7\end{array}$ & $\begin{array}{r}724 \\
153 \\
(21.1)\end{array}$ & 1214 \\
\hline 小梅 & $\begin{array}{c}\text { 受診 } \\
\text { 㳒体 } \\
\%\end{array}$ & $\begin{array}{r}56 \\
21 \\
37.5\end{array}$ & $\begin{array}{c}61 \\
17 \\
27.8\end{array}$ & $\begin{array}{r}46 \\
19 \\
41.2\end{array}$ & $\begin{array}{r}52 \\
17 \\
32.7\end{array}$ & $\begin{array}{r}48 \\
13 \\
27.1\end{array}$ & $\begin{array}{r}62 \\
20 \\
32.3\end{array}$ & $\begin{array}{c}52 \\
21 \\
40.3\end{array}$ & $\begin{array}{r}46 \\
17 \\
36.9\end{array}$ & $\begin{array}{r}67 \\
19 \\
28.4\end{array}$ & & & & $\begin{array}{r}490 \\
164 \\
(33.4)\end{array}$ & $=26.1$ \\
\hline
\end{tabular}

渗出性体質児がいるわけである。

2 ) 渗出(過敏)性体質児の点数 5 点以上群を皮虚・ 粘膜別にみた実数とその比率

個々の渗出性体質児の症状を皮䖈症状と粘膜症状に 大別してその点数の多い方を、また混合型もいずれか に分類し，まとめたのが第 3 表である。そこで各地区の 年度合計数を比率に直して求めてみると, 皮膚対粘膜 を郡部でまとめてみると，皮膚を 1 とすると粘膜は 0.82 となり，都市部では 1 に対し 1.61 となっていた。換言 すると郡部の乳児には粘膜症状より皮症症状の発現率 が多い一方, 都市部は粘膜症状の方が皮虚症状より発 現率が高いという結果がでていた。

この相違点についての解釈であるが, 皮虐粘膜の症 状発現の因子として郡部居住の乳児は都市部に比し厚 着の傾向にあるため, 発汗頻度が大であり，早期の医 療にめぐまれず，家族制度の因習にとらわれ，長老の 意見が左右するなどが皮病変を多くしているよう推 察される。一方, 都市部に粘膜症状の多い因子として 考えられることは居室の狭さ, 室温の寒暖の激しさ,
乳児をとりまく微生物の濃厚感染の強さ及び空気中の 有害物質の吸入など, 過密人口の弊害が推察される。

3 ) 各家庭の職種別からみた乳児の渗出 (過敏) 体 質点数（ 5 点以上）の各地区頻度

昭和 46 年の北海道農村医学会にて口演した時のもの が第 4 表で, 調査した年度も第 2 表の昭和 46 年 1 年間 のものである。職種別にみると, 郡部では農・酪農業 が第 1 位で, 5 点以上のものは $50.5 \%$ で他業を抜いて かなりの差をつけていた。以上からみても農・酪農業 家庭の乳児に渗出性体質のものが多いという点がうか がわれる。

4 ）栄養方法からみた渗出性体質を点数別にした各 地区頻度

これも昭和 46 年度のものであるが, 郡部のみで渗出 体質 5 点以上を栄養方法上からみると，母乳栄養児で

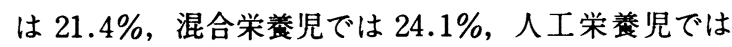
$34.2 \%$ と人工栄养児がやや多かった。これを都市部に おいてみると母乳栄養児の $9.5 \%$ に対して混合栄養児 で $22.7 \%$ ，人工栄養児では $19.3 \%$ と混合，人工の乳 
表 3 過敏（渗出）性体所児の皮唐，粘膜別にみた年度別の実数と比率

\begin{tabular}{|c|c|c|c|c|c|c|c|c|c|c|c|c|c|}
\hline 地域別 & $\begin{array}{l}\text { 症候 } \\
\text { 部位 } \\
\text { 別 }\end{array}$ & \begin{tabular}{|c|} 
昭和 \\
38
\end{tabular} & 39 & 40 & 41 & 42 & 43 & 44 & 45 & 46 & 47 & 48 & $\begin{array}{c}\text { 年度合計事 } \\
\text { 皮: 粘 }\end{array}$ \\
\hline 松 & $\begin{array}{l}\text { 皮 } \\
\text { 粘 }\end{array}$ & & & $\begin{array}{r}189 \\
46\end{array}$ & $\begin{array}{r}139 \\
97\end{array}$ & $\begin{array}{r}98 \\
161\end{array}$ & $\begin{array}{r}146 \\
75\end{array}$ & $\begin{array}{r}109 \\
91\end{array}$ & $\begin{array}{l}63 \\
81\end{array}$ & $\begin{array}{l}43 \\
36\end{array}$ & $\begin{array}{l}51 \\
43\end{array}$ & $\begin{array}{l}49 \\
45\end{array}$ & $1: 0.75$ \\
\hline 島 & $\begin{array}{l}\text { 皮 } \\
\text { 粘 }\end{array}$ & & & & & $\begin{array}{l}53 \\
79\end{array}$ & $\begin{array}{r}77 \\
121\end{array}$ & $\begin{array}{l}39 \\
40\end{array}$ & $\begin{array}{l}46 \\
40\end{array}$ & $\begin{array}{l}33 \\
44\end{array}$ & $\begin{array}{l}46 \\
25\end{array}$ & $\begin{array}{l}49 \\
33\end{array}$ & $1: 1.13$ \\
\hline 別 & $\begin{array}{l}\text { 皮 } \\
\text { 粘 }\end{array}$ & & & $\begin{array}{l}97 \\
68\end{array}$ & $\begin{array}{l}73 \\
70\end{array}$ & $\begin{array}{l}81 \\
82\end{array}$ & $\begin{array}{r}37 \\
115\end{array}$ & $\begin{array}{r}106 \\
62\end{array}$ & $\begin{array}{l}80 \\
43\end{array}$ & $\begin{array}{l}14 \\
31\end{array}$ & & & $1: 0.97$ \\
\hline 枝 & $\begin{array}{l}\text { 皮 } \\
\text { 粘 }\end{array}$ & & & & & & & & $\begin{array}{l}46 \\
35\end{array}$ & $\begin{array}{l}41 \\
22 \\
\end{array}$ & $\begin{array}{l}78 \\
66\end{array}$ & $\begin{array}{l}56 \\
31\end{array}$ & $1: 0.69$ \\
\hline 上 & $\begin{array}{l}\text { 皮 } \\
\text { 粘 }\end{array}$ & & & & & & & & & $\begin{array}{l}56 \\
53\end{array}$ & $\begin{array}{l}48 \\
35\end{array}$ & $\begin{array}{l}21 \\
17\end{array}$ & $1: 0.72$ \\
\hline 月 & $\begin{array}{l}\text { 皮 } \\
\text { 粘 }\end{array}$ & $\begin{array}{l}8 \\
5\end{array}$ & $\begin{array}{r}11 \\
4 \\
\end{array}$ & $\begin{array}{r}13 \\
8\end{array}$ & $\begin{array}{r}17 \\
9\end{array}$ & $\begin{array}{l}13 \\
13\end{array}$ & $\begin{array}{l}31 \\
28\end{array}$ & $\begin{array}{l}21 \\
12 \\
\end{array}$ & $\begin{array}{l}19 \\
14 \\
\end{array}$ & $\begin{array}{l}16 \\
11\end{array}$ & $\begin{array}{l}11 \\
12\end{array}$ & $\begin{array}{r}14 \\
8\end{array}$ & $1: 0.71$ \\
\hline 離 & $\begin{array}{l}\text { 皮 } \\
\text { 粘 }\end{array}$ & & & & & & & & & & & $\begin{array}{l}49 \\
29\end{array}$ & $1: 0.59$ \\
\hline 札 & $\begin{array}{l}\text { 皮 } \\
\text { 粘 }\end{array}$ & $\begin{array}{l}2 \\
6 \\
\end{array}$ & $\begin{array}{l}3 \\
3 \\
\end{array}$ & $\begin{array}{l}3 \\
4 \\
\end{array}$ & $\begin{array}{l}3 \\
5 \\
\end{array}$ & $\begin{array}{l}4 \\
7 \\
\end{array}$ & $\begin{array}{l}3 \\
6 \\
\end{array}$ & $\begin{array}{r}10 \\
6 \\
\end{array}$ & $\begin{array}{r}7 \\
11 \\
\end{array}$ & $\begin{array}{r}5 \\
17 \\
\end{array}$ & $\begin{array}{r}9 \\
16 \\
\end{array}$ & $\begin{array}{r}10 \\
9 \\
\end{array}$ & $1: 1.53$ \\
\hline 小 & $\begin{array}{l}\text { 皮 } \\
\text { 粘 }\end{array}$ & $\begin{array}{r}6 \\
11\end{array}$ & $\begin{array}{r}9 \\
10\end{array}$ & $\begin{array}{r}4 \\
13\end{array}$ & $\begin{array}{l}6 \\
7\end{array}$ & $\begin{array}{r}11 \\
9\end{array}$ & $\begin{array}{r}7 \\
14\end{array}$ & $\begin{array}{r}3 \\
14\end{array}$ & $\begin{array}{r}7 \\
12\end{array}$ & & & & $1: 1.70$ \\
\hline
\end{tabular}

表 4 職種別からみた乳児の皮庙, 粘膜過敏体質点数( 5 点以上)の頻度

\begin{tabular}{|c|c|c|c|c|c|c|c|}
\hline \multicolumn{2}{|c|}{ 地区別 家庭職種別 } & $\begin{array}{l}\text { 農 業 } \\
\text { 酪農業 }\end{array}$ & 勤 務 & 自営業 & 漁 業 & 計 & $\begin{array}{c}\text { 全例数に対する } \\
5 \text { 点以上群の } \\
(\%)\end{array}$ \\
\hline \multirow{2}{*}{ 松前地区 } & 例 数 & 14 & 85 & 36 & 193 & 328 & \multirow[b]{2}{*}{$(7.9)$} \\
\hline & 5点以上 & 5 & 5 & 2 & 14 & 26 & \\
\hline \multirow{2}{*}{$\begin{array}{l}\text { 渡 岛 } \\
\text { 福島地区 }\end{array}$} & 例 数 & 6 & 67 & 21 & 62 & 156 & \multirow[b]{2}{*}{$(31.4)$} \\
\hline & 5点以上 & 3 & 15 & 4 & 27 & 49 & \\
\hline \multirow{2}{*}{ 別海地区 } & 例 数 & 37 & 21 & 12 & 24 & 94 & \multirow[b]{2}{*}{$(29.8)$} \\
\hline & 5点以上 & 18 & 3 & 3 & 4 & 28 & \\
\hline \multirow{2}{*}{ 枝幸地区 } & 例 数 & 14 & 82 & 27 & 29 & 152 & \multirow[b]{2}{*}{$(29.6)$} \\
\hline & 5点以上 & 9 & 24 & 7 & 5 & 45 & \\
\hline \multirow{2}{*}{ 上川地区 } & 例 数 & 14 & 103 & 29 & - & 146 & \multirow[b]{2}{*}{$(56.0)$} \\
\hline & 5点以上 & 10 & 59 & 13 & - & 82 & \\
\hline \multirow{2}{*}{ 月形地区 } & 例 数 & 18 & 39 & 7 & - & 64 & \multirow[b]{2}{*}{$(25.0)$} \\
\hline & 5点以上 & 7 & 6 & 3 & - & 16 & \\
\hline \multirow{2}{*}{$\begin{array}{l}\text { 郡部計 } \\
\text { ( )\% }\end{array}$} & 例 数 & 103 & 397 & 132 & 308 & 940 & \multirow[b]{2}{*}{$(26.2)$} \\
\hline & 5点以上 & $52(50.5)$ & $112(28.2)$ & $32(24.2)$ & $50(16.3)$ & 246 & \\
\hline \multirow{2}{*}{ 札幌市内 } & 例 数 & 6 & 62 & 6 & & 74 & \multirow[b]{2}{*}{$(17.6)$} \\
\hline & 5点以上 & 1 & $10(16.1)$ & 2 & & 13 & \\
\hline
\end{tabular}


表 5 栄荃方法別にみた皮席，粘膜過敏体質点数別・各地区頻度.（主として昭. 46年度分)

\begin{tabular}{|c|c|c|c|c|c|c|c|c|c|c|c|c|c|}
\hline \multirow{2}{*}{\multicolumn{3}{|c|}{ 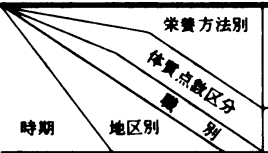 }} & \multicolumn{3}{|c|}{ 母 } & \multicolumn{3}{|c|}{ 混合 } & \multicolumn{3}{|c|}{ 人 } & \multirow{2}{*}{$\begin{array}{l}\text { 全例に対ナ } \\
\text { 35 点以上 } \\
\text { 群の }(\%)\end{array}$} & \multirow[t]{2}{*}{$\begin{array}{c}\text { 都蚛の } \\
(\%)\end{array}$} \\
\hline & & & $0-2$ & $3-4$ & 5 以上 & $0-2$ & $3-4$ & 5 以上 & $0-2$ & $3-4$ & 5 以上 & & \\
\hline $\begin{array}{l}\text { 昭. } 46.7 \\
\text { 手 榙 }\end{array}$ & 松前地区 & 漁 & 144 & 25 & 19 & 40 & 13 & 3 & 65 & 15 & 4 & $328 / 26=7.9$ & \multirow{7}{*}{$\begin{array}{c}\text { 都 } \\
74 / 13 \\
11 \\
17.6\end{array}$} \\
\hline $\begin{array}{l}\text { 昭. } 46.8 \\
\text { 乳 検 }\end{array}$ & $\begin{array}{l}\text { 湾 盆 } \\
\text { 福島地区 }\end{array}$ & 漁 & 35 & 12 & 21 & 19 & 7 & 12 & 25 & 9 & 16 & $156 / 49=31.4$ & \\
\hline $\begin{array}{l}\text { 昭. } 46.8 \\
\text { 乳 検 }\end{array}$ & 別海地区 & 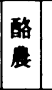 & 21 & 8 & 4 & 17 & 4 & 8 & 11 & 5 & 16 & $\frac{94}{28}=29.8$ & \\
\hline $\begin{array}{l}\text { 昭. } 46.8 \\
\text { 乳 检 }\end{array}$ & 枝幸地区 & 漁 & 38 & 9 & 16 & 29 & 4 & 8 & 22 & 5 & 21 & $152 / 45=29.6$ & \\
\hline $\begin{array}{l}\text { 昭. } 46 . \\
7 \sim 9 \\
\text { 定期徒钐 }\end{array}$ & 札䗷市内 & $\begin{array}{l}\text { 勏 } \\
\text { 和 }\end{array}$ & 17 & 2 & 2 & 13 & 4 & 5 & 22 & 3 & 6 & $74 / 13=17.6$ & \\
\hline $\begin{array}{l}\text { 昭.46.8 } \\
\text { 手 娭 }\end{array}$ & 上川地区 & 囬 & 18 & 6 & 24 & 6 & 9 & 17 & 13 & 12 & 41 & $146 / 82=56.0$ & \\
\hline \multirow[t]{2}{*}{$\begin{array}{l}\text { 昭.46.8 } \\
\text { 䑣 柣 }\end{array}$} & 月形地区 & 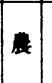 & 11 & 3 & 6 & 13 & 3 & 4 & 13 & 5 & 6 & $64 / 16=25.0$ & \\
\hline & \multicolumn{2}{|l|}{ 都路 } & \multicolumn{3}{|c|}{$21 / 2=9.5, \quad-420 / 90=21.4$} & \multicolumn{3}{|c|}{$\frac{22}{b^{2}} / 5=22.7, \quad \mathrm{D}^{216} / 52=24.1$} & \multicolumn{3}{|c|}{$\mathrm{B}^{31} / 6=19.3, \quad \mathrm{~s}^{304} / 104=34.2$} & & \\
\hline
\end{tabular}

児に比較的多くみられていることからすると，都虽共 に人工乳を与えているものに多いということが事実と なって表われてきている。それでは，その原因を何に 求めたらよいかということであるが, 現在までの文献 に，以上を解決してくれる論旨は見当らない。

5 ）渗出性体質を点数別にみた風邪疾患群並びにク 儿病の各地区頻度

風邪疾患群の範囲に入れたものは算, 咽頭, 喉頭部
のいわゆる上気道に感染が起り, 炎症性変化がくり返 される状態のものを一括した。クル病についてはX線 を使用した場合，腕関節部を撮影して，判定には Park の分類の $\mathrm{AD}, \mathrm{A}$ を陽性, 或は飯塚の分類の $(+)(+)$ を陽 性とした。X 線を使用できなかった地区では弘氏点数 法で 1.1 点以上を陽性とした。そこで受診乳児の渗出 性体質の点数別に, 第 6 表の如く $0 \sim 2$ 点群のほとん ど健康に近い者と, 5 点以上群の体質傾向の強い者の

表 6 皮虎，粘膜過敏体質を点数別にみた各地区罹病傾向（昭. 46年度調查）

\begin{tabular}{|c|c|c|c|c|c|c|c|c|c|c|}
\hline 体真点㓢 & & $\sim$ & 点群 & ( )内 & & & 点 & 人上群 & $(\mathrm{d}) \mathrm{P}$ & \\
\hline 地区別 & 例数 & & 队引易い & & ル病 & 例数 & & 队引易い & & クル病 \\
\hline 松前地区 & 249 & & $(8.0)$ & 4 & $(1.6)$ & 26 & 13 & $(50.0)$ & & $(26.9)$ \\
\hline 渡島福島地区 & 79 & & $(39.2)$ & 4 & $(5.05)$ & 49 & 21 & $(42.8)$ & 6 & $(12.2)$ \\
\hline 別 海 地 区 & 49 & 8 & $(16.3)$ & & $(6.1)$ & 28 & 11 & (39.3) & 5 & (17.9) \\
\hline 枝幸地区 & 89 & & $(19.1)$ & 11 & $(12.4)$ & 45 & 12 & $(26.7)$ & 9 & $(20.0)$ \\
\hline 札 沅地 区 & 52 & 4 & $(7.7)$ & 2 & $(3.8)$ & 13 & 2 & (15.4) & 2 & $(15.4)$ \\
\hline 上川地区 & 37 & 7 & $(18.9)$ & 5 & $(13.5)$ & 82 & 33 & $(40.2)$ & 16 & (19.5) \\
\hline 月 形地 区 & 37 & 5 & $(12.8)$ & 2 & $(5.4)$ & 16 & 4 & $(25.0)$ & 3 & $(18.7)$ \\
\hline 総計と平均 $(\%)$ & 592 & & $(15.5)$ & & $(5.2)$ & 259 & & $(37.1)$ & & $(18.5)$ \\
\hline
\end{tabular}


2 群に分け, 風邪疾患とクル病の頻度を地区別に検討 してみた。第 1 の風邪引き易い群は, 体質傾向の強い ものはそれだけ頻度も高くなっていた。つまり, 気道 粘膜の過敏な体質のものは環境刺戟によって上気道粘 膜に炎症性病変を起し，或はくり返す傾向が強いもの であろう。次にクル病の地区別頻度については, 確かに 最近は 20 年前と比較すると雲泥の如き差違で少なくは なってきた。昭和 46 年度で私の調査した 7 地区の 851 名の乳児中, クル病児が 79 名 $(9.3 \%)$ 発見されてい るところからすると，北海道もまだまだクル病がなく なったとはいえない。なお, 乳幼児に対する保健所活 動の積極的な地区は発症率が低いが，そうでない地区 はかなり高くみられている。これが体質点数とも関連が あって, 体質点が 5 点以上の群のクル病陽性率は 18.5 $\%$ に対して, 体質点 2 点以下群では $5.2 \%$ で $\frac{1}{3}$ 以下と なっていた。以上風邪引き易い乳児, クル病発症乳児 は渗出性体質傾向の強いほど罯病性も高いことから, やはり，体質の根本的改善を第 1 の予防対策として取 ク上げることの必要性が痛感されたわけである。
6) 母親の既往皮虎粘膜䍜患点数と乳児の渗出体質 点数との栄䓹方法別対比

親と子との相似性については遗伝学の領域において, かなり高い関連性についての報告がある。即ち, 顔貌, 表情, 性格, 体格, 体質などであるが，著者も乳児の 渗出性体質を点数で表わしたのを機会に，母親が幼少 時から現在までに皮席, 粘膜の疾患に時々罹患してい たか否かを第 6 表下記の 6 項目について聞き取り調査 をし，内 3 項目以上にハイに○をしたものを一応罹患 傾向ありと判断して点数をもって表わし, 乳児の体質 点数との間の関連を栄養方法別に対比してみた結果, 第 6 表の如く，母乳栄鉴を行なっている郡部の母親と 乳児との間に力イ自乗検定の結果， $1 \%$ 以下の危険率 をもって, 母親の 3 点以上群と乳児の体質点 5 点以上 との間に有意の差を認めた。人工栄誉の場合，或は都 市部などでは，有意性はあまり認められなかった結果 であった。

以上のことから，母体よりの母乳を通じて，母と子 の体質上の関連性のあることが判明したわけである。

表 7 母親の既往皮虐，粘膜䍜患点数と乳児の体質点数との栄養別対比（昭. 46年度調查）

\begin{tabular}{|c|c|c|c|c|c|c|c|c|c|c|}
\hline \multirow{3}{*}{ 地 区 } & \multirow{3}{*}{ 別 } & \multirow{3}{*}{$\begin{array}{l}\text { 乳 归 } \\
\text { 体質別 } \\
\text { 点 数 }\end{array}$} & \multicolumn{2}{|r|}{ 母 } & 乳 & 苃 & \multicolumn{4}{|c|}{ 人工 栄 養 } \\
\hline & & & \multirow{2}{*}{ 例数 } & \multicolumn{2}{|c|}{ 母親既往点数別 } & \multirow{2}{*}{$\alpha^{2}$ 検 定 } & \multirow{2}{*}{ 例数 } & \multicolumn{2}{|c|}{ 母親既往点数別 } & \multirow{2}{*}{$\alpha^{2}$ 検 定 } \\
\hline & & & & $0 \sim 2$ & $3 \uparrow$ & & & $0 \sim 2$ & $3 \uparrow$ & \\
\hline \multirow{2}{*}{ 松 } & \multirow{2}{*}{ 前 } & $0 \sim 4$ & 169 & 156 & 13 & \multirow{2}{*}{$11.03 \quad \mathrm{P}<0.01$} & 80 & 74 & 6 & \multirow{2}{*}{$1.42 \mathrm{P}<0.20$} \\
\hline & & $5 \uparrow$ & 19 & 12 & 7 & & 5 & 4 & 1 & \\
\hline \multirow{2}{*}{ 福 } & \multirow{2}{*}{ 島 } & $0 \sim 4$ & 47 & 42 & 5 & \multirow{2}{*}{$7.31 \quad \mathrm{P}<0.01$} & 34 & 31 & 3 & \multirow{2}{*}{$0.77 \quad \mathrm{P}<0.50$} \\
\hline & & $5 \uparrow$ & 21 & 15 & 6 & & 16 & 13 & 3 & \\
\hline \multirow{2}{*}{ 別 } & \multirow{2}{*}{ 海 } & $0 \sim 4$ & 29 & 25 & 4 & \multirow{2}{*}{$1.29 \mathrm{P}<0.30$} & 16 & 14 & 2 & \multirow{2}{*}{$0.96 \quad \mathrm{P}<0.50$} \\
\hline & & $5 \uparrow$ & 4 & 2 & 2 & & 16 & 13 & 3 & \\
\hline \multirow{2}{*}{ 枝 } & \multirow{2}{*}{ 幸 } & $0 \sim 4$ & 47 & 41 & 6 & \multirow{2}{*}{0} & 27 & 24 & 3 & \multirow{2}{*}{$0.65 \quad \mathrm{P}<0.50$} \\
\hline & & $5 \uparrow$ & 16 & 14 & 2 & & 21 & 17 & 4 & \\
\hline \multirow{2}{*}{ 上 } & \multirow{2}{*}{ 川 } & $0 \sim 4$ & 24 & 20 & 4 & \multirow{2}{*}{$0.55 \quad \mathrm{P}<0.50$} & 25 & 21 & 4 & \multirow{2}{*}{$0.66 \quad \mathrm{P}<0.50$} \\
\hline & & $5 \uparrow$ & 24 & 19 & 5 & & 41 & 38 & 3 & \\
\hline & 形 & $0 \sim 4$ & 14 & 12 & 2 & $170 \quad \mathrm{P}<020$ & 18 & 15 & 3 & 0 \\
\hline 月 & 形 & $5 \uparrow$ & 6 & 5 & 1 & $1.78 \quad P<0.20$ & 6 & 5 & 1 & 0 \\
\hline 郡 部 & 計 & $0 \sim 4$ & 330 & 296 & 34 & $11.03 \quad P<0.01$ & 200 & 179 & 21 & $1.18 \quad P<0.30$ \\
\hline & & $5 \uparrow$ & 90 & 67 & 23 & & 105 & 90 & 15 & \\
\hline 札 & 幌 & $0 \sim 4$ & 19 & 16 & 3 & $2.39 \mathrm{P}<0.10$ & 25 & 22 & 3 & $13 \quad \mathrm{P}<0.30$ \\
\hline & 恍 & $5 \uparrow$ & 2 & 1 & 1 & $2.095>0.10$ & 6 & 4 & 2 & \\
\hline 母親の既往 & 症の： & & 1. 湿 & $\begin{array}{l}\text { 苶に悩ま } \\
\text { イ, イイ }\end{array}$ & & $\begin{array}{l}2 . \\
\text { 風邪を引 } \\
\text { ハイ, }\end{array}$ & 易い & & $\begin{array}{l}\text { あれれ } \\
\text { ハイ }\end{array}$ & $\begin{array}{l}\text { 它ある } \\
\text { イイエ }\end{array}$ \\
\hline ハイの○一- & ol & & & $\begin{array}{l}\text { き出物力 } \\
\text { 1, } 1 \text { 1 }\end{array}$ & & $\begin{array}{l}\text { 5. 顔にしみ } \\
\text { ハイ、イ }\end{array}$ & & & $\begin{array}{l}\text { 体が } \\
\text { ハイ, }\end{array}$ & $\begin{array}{l}\text { lとなくかい } \\
\text { イイエ }\end{array}$ \\
\hline
\end{tabular}


そこで著者は次の段階として, 外胚葉系の結合組織 からなる皮虐, 粘膜の過敏現象の変化を, 栄養学の立 場からもっとも関連のあるビタミン Aについて先ず母 乳を調べ, ついで母親の血清中のビタミン $\mathrm{A}$ 量, そし て乳児の血清中のビタミン $\mathrm{A}$ 量を検索し, 乳児の渗出 体質の程度との間の関係について考察を行なった次第 である。

\section{III. 生化学的模索}

a. 母乳中のビタミン $\mathrm{A}$ 量

母乳中のビ夕ミン $\mathrm{A}$ 量を測定した文献は, 邦文とし て, 昭和 15 年以来で主として朝鮮, 九州, 関東, 関西, 東北などからで, 特に農村の主婦の母乳中のビタミン $\mathrm{A}$ 量を測定したのは田中の報告だけである。同氏の報 告のなかに, 例数は少なかったが, 農村主婦のうち乳 児にクル病のあった親の母乳のビタミン $\mathrm{A}$ 量及び脂肪 量が, いずれも少なかったとの事である。しかし著者 の述べる, 乳児の渗出性体質症状のある母親の母乳中
のビタミン $\mathrm{A}$ 量を測定した報告は見当らなかった。

\section{実験方法：}

脂肪の定量にはGerber ${ }^{77}$ の方法を用い, ビタミン A 定量にはCarr-Price 反応の変法である大島法をもって 実施した。測定にあたっては, 北海道厚生連, 旭川厚 生病院臨床検査技師の萩原弘二氏の御援助によりデー 夕を出して頂いたのである。

\section{実験成績 :}

母乳採取の地区は，上川町及び周辺の主として農家 の主婦で，乳児一斉健診に来所されたもののうち，母 乳栄養及び母乳を多く与えていた混合栄養をしており, 乳児に渗出性体質のあるものから at randomに 32 例を 抽出した。その内訳は純母乳栄養のもの 26 例, 混合栄 養のもの 6 例であった。その採取したのは昭和 46 年 8 月 7,8 の両日で, 採取し直ちに冷蔵庫に格納し, 上川 町から最も近い測定施設である九旭川厚生病院に持参し 直ちに実験に供したものである。

測定結果は，第 8 表と第 1 図の如くで, $20 \mathrm{IU} / 100 \mathrm{~m} \ell$

表 8 母乳中の V.A 量別にみた母乳栄養児の皮虚, 粘膜過敏体質 部位別頻度

（母乳栄養児のみ）

\begin{tabular}{|c|c|c|c|c|c|c|}
\hline 量 & $\begin{array}{l}\text { 呼吸器 } \\
\text { 粘 膜 }\end{array}$ & $\begin{array}{l}\text { 消化器 } \\
\text { 粘 膜 }\end{array}$ & 皮膚 & $\begin{array}{l}\text { 混合型 } \\
\text { 虚 } \\
\text { 粘 膜 }\end{array}$ & $\begin{array}{l}\text { 呼吸器 } \\
\text { 消华 } \\
\text { 以外留 } \\
\text { 粘 }\end{array}$ & $\begin{array}{l}\text { 人 数 } \\
\text { 計 }\end{array}$ \\
\hline 20 以下 & 3 & & 1 & 4 & 1 & 9 \\
\hline $21 \sim 40$ & 2 & 2 & 2 & 3 & 2 & 11 \\
\hline $41 \sim 60$ & 1 & 1 & & 1 & 2 & 5 \\
\hline 61 以上 & & & & & 1 & 1 \\
\hline 計 & 6 & 3 & 3 & 8 & 6 & 26 \\
\hline$\%$ & 23.1 & 16.5 & 16.5 & 30.8 & 23.1 & 100.0 \\
\hline
\end{tabular}

图1乳児の皮虚粘膜過敏症状を採点別にみた 母親の乳汁中の V.A 值の比較

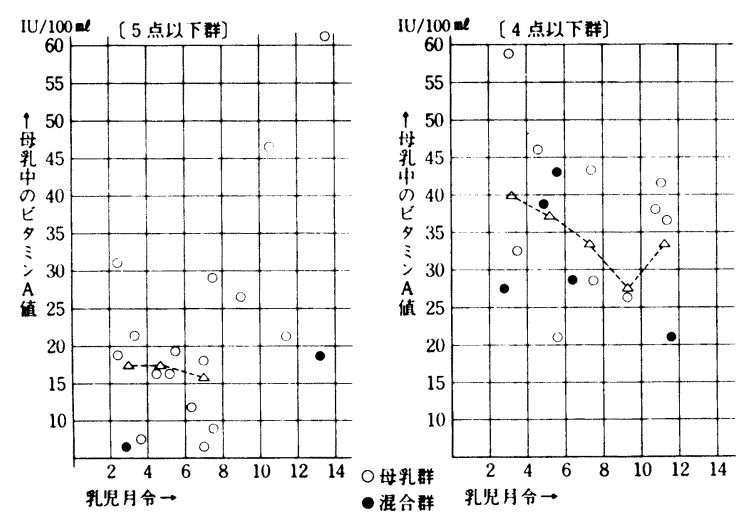

以下 9 例, $21 \sim 40 \mathrm{IU} / 100 \mathrm{~m} \ell$ のもの11例， $41 \mathrm{IU} / 100 \mathrm{~m} \ell$ 以上は 6 例にすぎなかった。特に低下していた 9 例は, 第 1 図の渗出体質 5 点以上群の乳児の母親の母乳でし められていた。体質の部位別にみると気道粘膜を初め 肛門部, 陰部, 口唇部等の粘膜の病変のあるものがほ とんどで, 皮虐のみの変化のものは僅かであった。

それに, 混合栄養の 6 例中 2 例は $20 \mathrm{IU} / 100 \mathrm{~m} \ell$ 以下 で，4例はいずれもそれ以上の值であった。

母乳中のビタミン A 量の含有の多夏が, 乳児の渗出 性過敏体質の症状にかなり左右されている結果がみら れた。このことから, 渗出性体質をひき起す母乳栄養 乳児の母親の体内のビタミン $\mathrm{A}$ が減少していることも 考えられ，またはFriend C.J の言う，A 摂取量は少な 
くなくても，アルブミン蛋白の摄取不足のためにAの 利用が充分でなく，乳児にかかる体質を具現せしめて いるのかについては, 今後この方面の検索も必要とな ってくる。

\section{b. 母親血清中のビタミン A 量}

本検索は昭和 47 年 8 月 26,27 両日の上川地区の乳 児一斉健診の際に，母乳栄養児の母 9 名, 混合栄養児 の母 3 名，人工栄養児の母 5 名よりそれぞれ採血し， 血清を遠心分離し, 氷室内に保持し, 旭川厚生病院検 查室にて定量して頂いた。昨年同様, 萩原技師にお願 いした。

\section{実験方法並びに実験成績：}

Carr-Price 反応比色法によった。標準ビタミンとし ては日本薬局方 Vitamin A 検定用として 10,000 IU/g を使用す。(第 9 表参考)

採血実数は 18 例であったが, 混合栄養の母親の採血 量が少なかった 1 例を除き，データとして，のったの は 17例であった。この方法による正常值範囲は 90〜291 $\mathrm{IU} / \mathrm{d} \ell$ 故, 今回の測定結果で低下していたのは 1 名 $(71$ $\mathrm{IU} / \mathrm{d} \ell)$ で, この婦人の乳児は母乳栄養の 4 力月児で あったが, 渗出体質点数は 6 点であり, 母親自身の既 往症点数は 4 点であった。また, $300 \mathrm{IU} / \mathrm{d} \ell$ 以上の高 值の 5 名についてみると, 児の体質点数は偶然か全例 2 点以下であり，母親の既往点数は 3 点が 1 人， 2 点 が 2 人, あとは 0 点であった。以上の結果から, 推論 として, 母親の血清内ビタミン A 量の多骞と乳児の渗 出性体質の発生とは因果関係は浱厚とはいえないが, しかし無関係ともいえず，これには他の関連因子が影 響しているものと思考される。鷹筩年) の報告の中にも 皮虚病や肝疾患或は内分泌障碍の場合, 血清中のビ夕 ミン $\mathrm{A}$ 值の低下があるとのことからみて, 前述の, 母
親の既往点数の高いことと $\mathrm{A}$ 值の低いのは関連があろ うと思われる。

c. 乳児血清中のビタミン A 量

これに関する内外の文献は少ない。主なるものは, 宮崎が Bessey の方法を用い Beckman 光電光度計 DU 型にて吸光值を測定している。また，松見も，同様の 方法で血中 $\mathrm{A}$ 浱度を測定している。何せ乳児の場合採 血が至難なため, 血清として $0.5 \mathrm{~m} \ell$ 以上は容易でない。 となると微量で可能な方法は, 紫外線の一定範囲内に おいてビタミン A に特異な蛍光を発する部分をとらえ (Primary Filter), ついで Secondary Filter の波長か らその平均值を求める方法をもちいた。吸光值は Beck$\operatorname{man}$ の蛍光光度計を使用した。

以上の測定操作は手元にないので, 札幌臨床検査セ ンターの分析部の佐藤貫太郎部長に御伤頼申したとこ ろ, 快く引きうけられ、デー夕を頂いた。なお,この 研究材料は, 昭和 48 年 8 月 11 日実施した上川地区乳 児一斉健診の際，渗出性体質児，健康児を at random に 18 名えらび採血した。ついで昭和 48 年 9 月 $3 \sim 5$ 日 の間，北見枝幸地区の乳児一斉健診の際，前，上川地 区同様 at randomに17名選び採血をし，それぞれ直ち に血清を分離し，持ち帰り，水室内に保存した。35検 体中 2 検体は量不足と溶血のため測定不能故，33例に ついての結果は次の第 9 表の如くである。33例の平均 蛍光比が 45 前後であった。第 10 表にみる様に上気道粘 膜に反応の強いものは蛍光比の低下,つまりビタミン A の濃度の低下に大体比例していた。そこで渗出性体質 の点数と蛍光比との相関をみると第 2 図の如く逆相関 を示し，その係数は一- 0.382 を示していた。つまり， 体質点数の高いほど蛍光比が低くなっている傾向を示 していた。

表 9 過敏（渗出性）体質児の症状別にみた母の血清中 V.A 量の分布

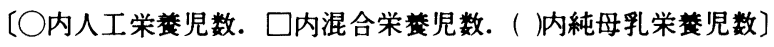

\begin{tabular}{|c|c|c|c|c|c|c|}
\hline 量的分類 $\mathrm{IU} / \mathrm{d} \ell$ & $\begin{array}{l}\text { 呼吸器 } \\
\text { 粘 膜 }\end{array}$ & $\begin{array}{l}\text { 消化器 } \\
\text { 粘 膜 }\end{array}$ & 皮虚 & $\begin{array}{l}\text { 混合型 } \\
\text { 虚 } \\
\text { 粘 膜 }\end{array}$ & $\begin{array}{l}\text { 呼吸器 } \\
\text { 消化梈 } \\
\text { 粘膜 }\end{array}$ & $\begin{array}{l}\text { 人 数 } \\
\text { 計 }\end{array}$ \\
\hline 99 以下 & & & & $1(1)$ & & 1 \\
\hline $100 \sim 199$ & $1(1)$ & & $1(1)$ & $4 \frac{(3)}{[1]}$ & & 6 \\
\hline $200 \sim 299$ & $2_{(1)}^{(1)}$ & 11 & 11 & & 1 (1) & 5 \\
\hline 300 以上 & & & $1(1)$ & 1 (1) & $3 \frac{(1)}{(2)}$ & 5 \\
\hline 計 & 3 & 1 & 3 & 6 & 4 & 17 \\
\hline$\%$ & 17.7 & 5.8 & 17.7 & 35.3 & 23.5 & 100.0 \\
\hline
\end{tabular}


衰10 臨床症状別からみた患児の血清内 V.A の蛍光比

\begin{tabular}{|c|c|c|c|c|c|}
\hline & \multirow{2}{*}{ 例 数 } & \multicolumn{3}{|c|}{ 血清 V.A の蛍光比 } & \multirow{2}{*}{ 偏 差 値 } \\
\hline & & 最小比 & 最大比 & 平均 & \\
\hline $\begin{array}{l}<ク \text { 返す感 } \\
\text { 冒 } \\
\text { 罪 患 乳 児 }\end{array}$ & 9 & 24 & 58 & 36.6 & 3.4 \\
\hline 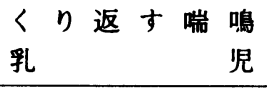 & 4 & 26 & 45 & 39.5 & 3.9 \\
\hline $\begin{array}{l}\text { くり返す湿疹, 汗疹 } \\
\text { 罪 } \\
\end{array}$ & 6 & 25 & 48 & 39.3 & 3.4 \\
\hline $\begin{array}{l}\text { 便秘，下溂(体所的) } \\
\text { 時々くり返す乳児 }\end{array}$ & 5 & 28 & 56 & 44.0 & 1.9 \\
\hline 無 病 乳 児 & 9 & 56 & 88 & 68.4 & 4.6 \\
\hline
\end{tabular}

图 2 乳児期体質過敏程度と血清内ビタミン A の相関

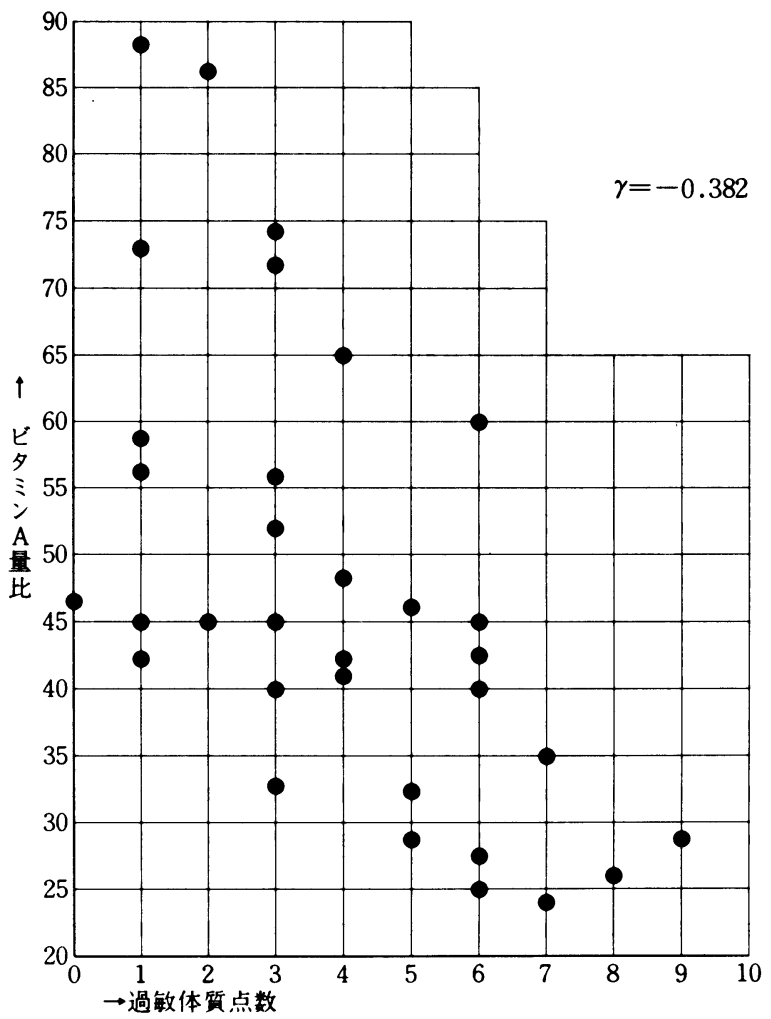

IV. 総

括

以上, 著者が都市 2 地区, 郡部 7 地区の乳児の健診 において渗出性体質を症状発現別にえり出し，それの 統計的処理を行い，また，母と子の体質上の関連性に ついてのべると共に, 渗出性体質を栄䬭学的立場より 最も影響のあると思われるビタミン Aについて少しく
検索を行なった結果，その詳細は述べてきたので，こ こにまとめてみると次の如くである。

(1)年代が新しくなるにつれて次第に渗出性体質が増 加の傾向を帯びてきている。しかし健診の頻度が重な っていく地区では滅少していく好ましい傾向が見えて いた。最近の乳児は体位は上昇してきているが，体力 面で, 微生物や外界の諸刺戟に対して皮虚や粘膜の抵 抗性は弱く, 罹病と結びっく傾向が多くなってきた。

(2)地区別に職種毎の体質の程度の状況をみると農業, 酪農家庭の乳児に多かった。

(3)生後 4 力月以上の者は 4 力月の時点, 以下のもの は調査時の月令でそれぞれ栄養方法を分け体質採点別 にみると，母乳より人工に高いものが多かったが，そ の比率としては, $1: 1.5: 1.7$ で有意差は認められな かった。

郡，市でクル病罹患傾向を比較すると，郡部の方の 渗出体質点数の高いものに有意差がみられた。

(4)母親の既往において皮虚粘膜の傾向の高いものか ら生れた乳児に，体質採点 5 点以上における有意差は 郡部で $1 \%$ 以下の危険率で高い值を示していた。都市 では有意差はほとんどなかった。

以上の諸点から, 郡部, 特に農村 ・酪農村の乳児は 皮㲊の抵抗性が低下しているため, 異常反応を起すも の多く，また，渗出性体質の点数の高いものはクル病 䍜患も多かった。なお，母親の既往に皮虐粘膜罹患傾 向の強いものからの乳児に体質点数の高いものが多か つた。

換言すると，先天性の体質遣伝もさることながら， これを栄養学的な立場から, 皮虐粘膜骨系統の抵抗力 の薄弱と密接な関連性のあるものは先ずビタミン Aで あるから，少しくビタミン A について母と子の両面か 
ら検索した結果をのべると次の如くである。

(1)母乳中のビタミン A 量が低下している場合, 母乳 栄養児の渗出性体質中粘膜（特に上気道）の抵抗力の 弱いものに多くみられた。

(2)母親の血清中ビタミン A 量の低下しているものは 数の上では少ないので何ともいえない。今後なお, 例 数を加えて再検討したい。

(3)乳児の血清中ビタミン A 量の低下しているものは 気道性疾患のものに多くみられた。なお，無病乳児と 上気道過敏乳児との間には $2 \%$ の危険率で有意差があ つた。

\section{V. おわりの聿葎}

郡部, 特に農村・酪農村居住の乳児には渗出性体質 傾向が高く，その成因として考えられるのは, ビタミ ン $\mathrm{A}$ 低下と体質の頻度の高いものとの間に負の相関を 示していた。

なお，現在渗出性体質の改善策の一つとしてビタミ ン $\mathrm{A}$ 製威の内服及び皮膚塗擦を行い, 同時に栄養食品 としてビタミンA 含有のもののスープとか食物を軟菜, 離乳副菜として与えつつ経過観察中である。

稿を終えるに当って, この研究に対し, 北海道晨村医学会から昭 和 $46,47,48$ 年の 3 年間助成金の交付をうけたことに対し深甚の
謝意を表する。なお，本研究の統計料に御協力頂いた松前町， 福島町, 上川町, 月形町, 別海町, 利尻町, 礼文町, 枝幸町, 小 梅市若竹町並びに札棏市白石町内会婦人部の皆様に感謝の意を表 する。併せて, 生化学的検索に御指導御援助を頂いた旭川厚生病 院長菅野二郎博士, 同臨床検査技師萩原弘二氏, 札㹸臨床検査七 ンター化学分析部長佐藤貫太郎氏に深甚の謝意を表する。最後に 釈児一斉健診に絶大な御協力をおしまず積極的にその運営に当つ て頂いた道立稚内保健所, 同旭川保健所, 同中標津保健所, 同木 古内保健所, 同岩見沢保健所の所長先生並びに担当職買に深謝す る次第である。

\section{* 考文献}

1) Czerny, A. : 臨床小児神経症, 岩波文門著, 初版, 190頁 (1964) より引用

2）遠城寺宗徳：臨片内科小児科， 2 巻 3 号， 7 頁 (1947)

3）Moro：体質医学，木田文夫著，初版，69頁 (1946)より引用

4) Park：小児科臨床, 小林㮛樹碖文, 4 巻 12 号, 14頁 (1951) 上 り引用

5）饭塚氏分類：小児科臨床，6巻11号，24頁(1953)より引用

6）弘氏点数法 (弘好文)：北大小児科発行パンフレット(1950)よ り引用

7）田中典和：小児科臨床, 15巻10号, 84頁 (1962)より引用

8）大岛氏法：農芸化学会雑誌, 15卷, 533頁 (1939)より引用

9) Friend C.J. 外 3 : Brit. J. Nutr., Vol. 15, P.231(1961)

10)鹰觜研一：日本皮虚科学会雑誌, 79巻 6 号, 466頁(1969)及び 同誌, 80巻 1 号, 56頁 (1970)

11) Bessey O. A. 外 : J. B. C., Vol. 159, P.465(1945)一日本小归科 学会雑誌, 60 巻 4 号, 249 頁 (1956) 及び同誌60巻 5 号, 289 頁 (1956)宮䗁叶論文一より引用

\title{
Clinical Study on the Ruling Factors for Exudative Constitution of Rural Babies
}

\author{
Shigemoto TASAKA, M.D.*
}

The exudative constitution (hypersensitivity of skin and mucous membrane) is much observed in infant stage, showing hypersensitive reactions of skin and mucous membrane to the environmental stimuli, very often together with the resultant physical disturbance.

The author, first of all, attributed the changes of hypersensitive phenomena of the skin and mucous membran originated from the outer stratum of embryo, to the changes or reduction in the Vitamin A content, as a nutritional factor.

Since Vitamin A plays a dominant role in the growth of the combined tissue such as skin and mucous membrane, a clinical, biochemical study was made, and the results are briefly reported as follows :

(A) After statistical observations of exudative constitution in infants,

1) The morbidity was 26 per cent in rural districta as compared with 18 per cent in urban communties.

2) Even in rural districts, the morbidity was 50.5 per cent in cases of farming (including dairying) families as compared with 28.2 per cent in cases of salaried classes such as instructors, public servants as well as company and 1 or factory employees. 
3) The ratio of physical changes of skin to those of mucous membrane was $1: 0.79$ in cases of suburban districts including farming villages, as compared with that of $1: 1.62$ in urban areas-which implies more skin changes in rural districts.

(B) With respect to the biological examination of nursing mothers and their infants,

1) Vitamin A content of the nursing mother's milk showed a higher decreasing tendency in the infants with advanced symptoms,

2) Vitamin A content of the suckling mother's blood sera showed a higher decreasing tendency in the infants with advanced disturbance of skin and mucous membrane.

3) Vitamin A content of the infant's blood sera showed a higher decreasing tendency in the infants with advanced disturbance of skin and mucous membrane, the correlation coefficient being 0.382 .

From the above-mentioned observations, it is concluded that exudative constitution is found more in rural districts and that the more of such tendency is found, the more tendency of Vitamin A content decline.

In addition, the results of internal and ointmental application of Vitamin $A$ to such cases are now being observed.

(The author wishes his deep graditude to the kind subsudy donated by Hokkaido Rural Medicine Association for this research, continously three times, in the years of 1971, 1972 and 1973).

*Charge of Childrencare and Pediatry Health, Hokkaido Nutrition Junior College 